\title{
EFFECT OF ZINGIBER OFFICINALE ON MORTALITY PERCENTAGE AND COCOON SHELL RATIO OF THE SILKWORM, BOMBYX MORI L.
}

\author{
Nagat Hamed Soliman \\ Plant Protection Department, Faculty of Agriculture, El Fayoum University, Egypt.
}

\begin{abstract}
The effect of Zingiber officinale was studied on mortality percentages and cocoon shell ratio of silkworm, Bombyx mori during spring season of 2015 at Plant Protec. Dept. Fac. of Agric., El Fayoum Univ. The powder of $Z$. officinale was dissolved in distilled water to prepare different concentrations $(10,20,30,40$ and $50 \mathrm{mg} / \mathrm{ml}$.). In the present study, results showed that, the concentration $20 \mathrm{mg} / \mathrm{ml}$. of $Z$. officinale occupied the first category to reduce $1^{\text {st }}, 2^{\text {nd }}$ and $3^{\text {rd }}$ instars mortality percentages. While $40 \mathrm{mg} / \mathrm{ml}$. of Z $Z$. officinale occupied the first category for reducing $4^{\text {th }} \& 5^{\text {th }}$ instars mortality percentages and improving cocoon shell ratio.
\end{abstract}

\section{NTRODUCTION}

The mulberry silk worm (Bombyx mori L.) is of great economic importance as a foreign exchange earner for many silk producing countries. It is a beneficial insect reared for the valuable commodity silk. Diseases attack the silkworm of all stadiums, and can inhibit the silkworm rearing (Krishnaswami et al., 1992).In tropical countries, mulberry silk worm is continuously reared and this makes it highly susceptible to pathogens and hence occurrence of diseases is a major constraint (Samson et al., 1998) . Zingiber officinale is one of the important medicinal plant, the major active components is gingerol [5.hydroxy.1.(4.hydroxy.3.methoxy phenyl) decan.3.one] is the most abundant constituent in the gingerol series. The powdered rhizome contains $3.6 \%$ fatty oil, $9 \%$ protein, $60.70 \%$ carbohydrates, $3.8 \%$ crude fiber, about $8 \%$ ash, $9.12 \%$ water and $2.3 \%$ volatile oil (Kiuchi et $\boldsymbol{a l} .$, 1993) and (Mustafa $\boldsymbol{e t}$ al., 1993). Through out serving it was found that the promotional literature related to use aromatic and medicinal plant parts on B. mori characters were low. Therefore, the present study has been planned to determine, the effect of Zingiber officinale on some parameters of silkworm, B. mori L.

\section{MATERIALS AND METHODS}

Zingiber officinale was examined on mortality percentages and cocoon shell ratio of silkworm, Bombyx mori during spring season of 2015 at Plant Protec. Dept. Fac. of Agric., El Fayoum Univ. Egg box of silkworm, $B$. mori (Egyptian hybrid) were obtained from the Seric. Res. Dept., Plant Protec. Res. Inst, Agric. Res. Center. Dokki, Giza. Powder (dried rhizome) of $Z$. officinale were dissolved in distilled water to prepare different concentrations.

Fayoum J. Agric. Res. \& Dev., Vol. 31, No.1, January, 2017 
Larvae of $B$. mori were reared on fresh mulberry leaves (Morus alba var. indicia) under laboratory conditions $\left(28 \pm 2^{\circ} \mathrm{C}, 70 \pm 5 \% \mathrm{RH}\right)$. At the beginning of the $1^{\text {st }}$ instar, larvae were divided into five groups (in addition to the control). Each group was divided into five replicates (each of hundred larvae). Each replicate was reared in carton tray $\left(30 \times 15 \times 4^{\mathrm{cm}}\right)$.

Larvae of each group were fed on mulberry leaves sprayed with one of the different concentrations $(10,20,30,40$ and $50 \mathrm{mg} / \mathrm{ml}$.) of $Z$. officinale at the first and second day of all instars after drying on ambient air temperature for one minute. The control was fed on mulberry leaves sprayed with distilled water . Mortality percentages of all instars were recorded and cocoon shell ratio were calculated for all the replications of treatments and the control. Data was analyzed by ANOVA through statistical package for social science (SPSS) to find out the significance between treated and control (Berkowitz and Allaway, 1998). Means were separated by (L.S.D at $0.05 \%$ ).

\section{RESULTS AND DISCUSSION}

Data in Table (I) show that, The means of the $\mathbf{1}^{\text {st }}$ instar mortality percentages ranged between $10.40 \%$ for $20 \mathrm{mg} / \mathrm{ml}$ and $15.80 \%$ for $50 \mathrm{mg} / \mathrm{ml}$ of $Z$. officinale. The mean values of mortality percentage at the $2^{\text {nd }}$ instar ranged between $9.00 \%$ for $20 \mathrm{mg} / \mathrm{ml}$ and $11.80 \%$ for $40 \mathrm{mg} / \mathrm{ml}$ of $Z$. officinale. The means of the $3^{\text {rd }}$ instar ranged between $8.20 \%$ for $20 \mathrm{mg} / \mathrm{ml}$ of Z. officinale and $9.60 \%$ for $10 \mathrm{mg} / \mathrm{ml}$ of $Z$. officinale compering to $10 \%$ for control.

TABLE (I):Effect of Zingiber officinale concentrations on $1^{\text {st }}, 2^{\text {nd }}$ and $3^{\text {rd }}$ instars mortality percentages (\%) of silkworm, Bombyx mori $\mathrm{L}$.

\begin{tabular}{|c|c|c|c|}
\hline $\begin{array}{c}\text { Concentrations } \\
(\mathbf{m g} / \mathbf{m l} \mathbf{)})\end{array}$ & $\begin{array}{c}\mathbf{1}^{\text {st }} \text { instar mortality } \\
\text { percentages (\%) }\end{array}$ & $\begin{array}{c}\mathbf{2}^{\text {nd }} \text { instar } \\
\text { mortality } \\
\text { percentages (\%) }\end{array}$ & $\begin{array}{c}\mathbf{3}^{\text {rd }} \text { instar } \\
\text { mortality } \\
\text { percentages (\%) }\end{array}$ \\
\hline 10 & $14.60 \pm 0.400000 \mathrm{~b}$ & $11.60 \pm 0.678233 \mathrm{~b}$ & $9.60 \pm 0.678233$ \\
\hline 20 & $10.40 \pm 0.400000 \mathrm{a}$ & $9.00 \pm 0.547723 \mathrm{a}$ & $8.20 \pm 0.583095$ \\
\hline 30 & $15.20 \pm 0.374166 \mathrm{~b}$ & $\begin{array}{c}11.00 \pm 0.547723 \\
\mathrm{ab}\end{array}$ & $9.20 \pm 0.583095$ \\
\hline 40 & $14.60 \pm 0.400000 \mathrm{~b}$ & $\begin{array}{c}10.80 \pm 0.663325 \\
\mathrm{ab}\end{array}$ & $8.80 \pm 0.374166$ \\
\hline 50 & $15.80 \pm 0.663325 \mathrm{~b}$ & $11.20 \pm 0.374166 \mathrm{~b}$ & $8.80 \pm 0.583095$ \\
\hline control & $15.40 \pm 0.509902 \mathrm{~b}$ & $\begin{array}{c}10.60 \pm 0.509902 \\
\mathrm{ab}\end{array}$ & $10.00 \pm 0.632456$ \\
\hline F value & $* *$ & $*$ & - \\
\hline LSD at 0.05\% & 1.369 & 1.642 & - \\
\hline
\end{tabular}

The $\mathbf{4}^{\text {th }}$ instar mortality percentages ranged between $6.40 \%$ for $40 \mathrm{mg} / \mathrm{ml}$ and $8.60 \%$ for $20 \mathrm{mg} / \mathrm{ml}$ of $Z$. officinale. While the mortality percentage means of th $\mathbf{5}^{\text {th }}$ instar ranged between $5.60 \%$ for $40 \mathrm{mg} / \mathrm{ml}$ and $7.80 \%$ for $20,30,50 \mathrm{mg} / \mathrm{ml}$ of $Z$. officinale compering to $8.20 \%$ for control. The means

Fayoum J. Agric. Res. \& Dev., Vol. 31, No.1, January, 2017 
EFFECT OF ZINGIBER OFFICINALE ON MORTALITY.

of the cocoon shell ratio ranged between $17.50 \%$ for $50 \mathrm{mg} / \mathrm{ml}$ and $19.73 \%$ for $40 \mathrm{mg} / \mathrm{ml}$ of $Z$. officinale. While the cocoon shell ratio of the control recorded $18.37 \%$ according to data in Table (II).

TABLE (II):Effect of Zingiber officinale concentrations on $4^{\text {th }} \& 5^{\text {th }}$ instars mortality percentages $(\%)$ and Cocoon shell ratio (\%) of silkworm, Bombyx mori L.

\begin{tabular}{|c|c|c|c|}
\hline Concentrations (mg/ml.) & $\begin{array}{c}\mathbf{4}^{\text {th }} \text { instar mortality } \\
\text { percentages }(\boldsymbol{\%})\end{array}$ & $\begin{array}{c}\mathbf{5}^{\text {th }} \text { instar mortality } \\
\text { percentages }(\boldsymbol{\%})\end{array}$ & $\begin{array}{c}\text { Cocoon shell ratio } \\
(\boldsymbol{\%})\end{array}$ \\
\hline 10 & $8.40 \pm 0.509902 \mathrm{~b}$ & $6.80 \pm 0.916515 \mathrm{ab}$ & $17.82 \pm 0.3042 \mathrm{~b}$ \\
\hline 20 & $8.60 \pm 0.447214 \mathrm{~b}$ & $7.80 \pm 0.583095 \mathrm{~b}$ & $18.29 \pm 0.3008 \mathrm{~b}$ \\
\hline 30 & $8.00 \pm 0.400000 \mathrm{ab}$ & $7.80 \pm 0.374166 \mathrm{~b}$ & $18.53 \pm 0.1354 \mathrm{~b}$ \\
\hline 40 & $6.40 \pm 0.244949 \mathrm{a}$ & $5.60 \pm 0.400000 \mathrm{a}$ & $19.73 \pm 0.3377 \mathrm{a}$ \\
\hline 50 & $8.40 \pm 0.748331 \mathrm{~b}$ & $7.80 \pm 0.374166 \mathrm{~b}$ & $17.50 \pm 0.2087 \mathrm{~b}$ \\
\hline control & $8.40 \pm 0.400000 \mathrm{~b}$ & $8.20 \pm 0.734847 \mathrm{~b}$ & $18.37 \pm 0.3543 \mathrm{~b}$ \\
\hline F value & $*$ & $*$ & $*$ \\
\hline LSD at 0.05\% & 1.410 & 1.751 & 1.940 \\
\hline
\end{tabular}

Mortality percentages of the five larval instars were decreased and cocoon shell ratio were improved in the treated groups of $Z$. officinale when compared to control as presented in Table (I \& $\mathbf{I})$. These might be due to the effect of Z. officinale as anti microbial (Gugnani \& Ezenwanze, 1985 \& James et al., 1999 and Ficker et al., 2003), anti-oxidant (Jagetia et al., 2003 and Kim et al., 2005) and stimulate digestion and absorption (Mowrey \& Clayson, 1982 and Stewart et al., 1991).

\section{REFERENCES}

Berkowitz, D. and Allaway, A. (1998). Statistical package for social sciences (SPSS), version 7.5 for windows NT/windows95, 30-132.

Ficker, C. ;Smith,M. L.; Akpagana, K. ; Gbeassor, M. ; Zhang, J. ; Durst, T. ; Assabgui, R. and Arnason, J. T. (2003). Bioassay, guided isolation and identification of antifungal compounds from ginger. Phytother. Res, 17: 897-902.

Gugnani, H. C. and Ezenwanze, E. C. (1985). Antibacterial activity of extracts of ginger (Zingiber officinale) and African oil bean seed (Pentaclethora macrophylla). J Commun. Dis, 217: 233-240.

Jagetia, G. C. ; Baliga, M. S. ; Venkatesh, P. and Ulloor, J. N. (2003). Influence of ginger rhizome (Zingiber officinale) on survival, glutathione and lipid peroxidation in mice after whole body exposure to gamma radiation. Radiat Res, 160: 584-592.

James, M. E. ; Nannapaneni, R. and Johnson, M. G. (1999). Identification and characterization of two bacteriocinproducing bacteria isolated from garlic and ginger root. J Food Prot, 62: 899-904.

Fayoum J. Agric. Res. \& Dev., Vol. 31, No.1, January, 2017 
Nagat Hamed Soliman

Kim, H. W. ; Murakami, A. Abe, M. ; Ozawa, Y. ; Morimitsu, Y. ; Williams, M. V. and Ohigashi, H. (2005). Suppressive effects of mioga ginger and ginger constituents on reactive oxygen and nitrogen species generation, and the expression of inducible pro. inflammatory genes in macrophages. Antioxid Redox Signal, 7: 1621-1629.

Kiuchi, F. ; Shibuya, M. and Sankawa, V. (1993). Inhibitors of prostaglandin biosynthesis from ginger. Chem Pharm Bull, 30 : 754.

Krishnaswami, S. ; Narashimanna, Suyananrayana, S. K. and Kumararaj, S. (1992). Sericulture manual 2. silkworm rearing. Oxford and IBH, NewDelhi.

Mowrey, D. B. and Clayson, D. E. (1982). Motion sickness, ginger and psychophysics. Lancet i, 6557.

Mustafa, T. ; Srivastava, K. C. and Jensen, K. B. (1993). Drug development report: Pharmacology of ginger, Zingiber officinale. $\mathrm{J}$ Drug. Dev, $6: 24-28$.

Samson , M. V. ; Singh, R. N. and Sasidharan, T. O. (1998). Resham jyothi - a wide spectrum bed disinfectant. Indian silk 37: 9-10.

Stewart, J. ; Wood, M. J. ; Wood, C. D. and Mims, M. E. (1991). Effects of ginger on motion sickness susceptibility and gastric function. Pharmacology, 42: 111-115.

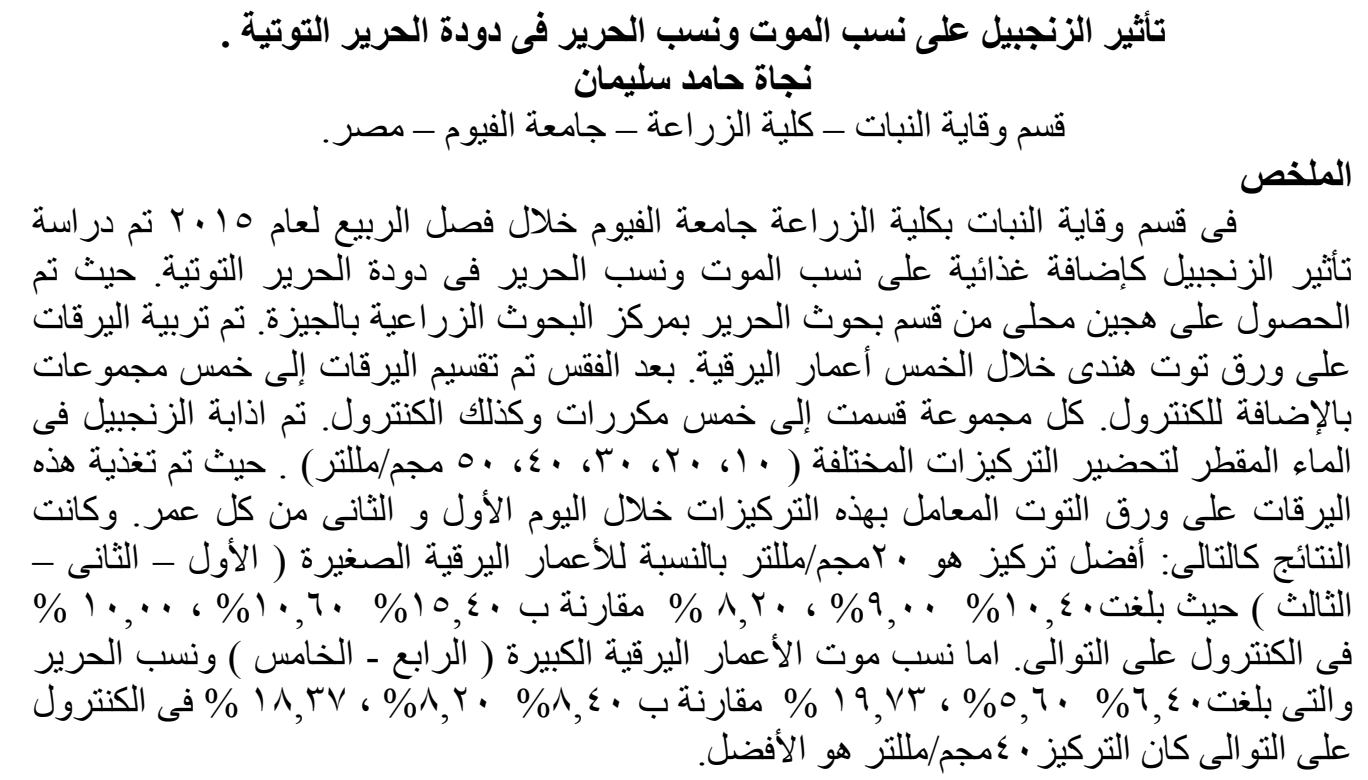

Fayoum J. Agric. Res. \& Dev., Vol. 31, No.1, January, 2017 